\title{
Experiences with a rat bio-assay in the diagnosis of the Zollinger-Ellison syndrome
}

\author{
CHRISTINE G. THOMSON, I. G. M. CLEATOR, AND W. SIRCUS ${ }^{1}$ \\ From the Teaching and Research Centre and the Gastro-Intestinal Unit, the Western General Hospital, \\ Edinburgh, and the Departments of Clinical Chemistry, Clinical Surgery, and Medicine (Western \\ General Hospital), University of Edinburgh.
}

SUMMARY Reported here are the assay results, using the anaesthetized rat preparation of Lai (1964), of plasma from patients known or suspected to have peptide-secreting adenomata and these are compared with assays carried out on plasma from patients whose clinical history excluded such pathology. It is suggested that these demonstrate that this technique is of diagnostic value in this condition and that it has practical advantages over other bio-assay methods currently available and physiological advantages over immunological methods.

It may well be that identification of the presence of tumour in these patients may first be made by immunological techniques to be followed by functional identification using a bioassay procedure such as is described here.

In the first description of the clinical entity which linked recurrent peptic ulceration and 'gigantic' gastric hypersecretion with islet-cell tumours of the pancreas, the authors (Zollinger and Ellison, 1955) suggested that the basis of the syndrome might be the secretion into the circulation of a humoral substance from the tumour. The extraction from such tumour of a gastric secretagogue with physiological properties similar to those of antral gastrin was subsequently reported by Gregory, Tracy, French, and Sircus (1960). The hypothesis of Zollinger and Ellison was supported by the demonstration of a gastric secretagogue in the serum and gastric juice of two patients with the disease (Sircus, 1964) and subsequently by Banks and Marks (1964) in a further case.

The evidence that the substance that could be extracted from the tumours was similar to, if not identical with, gastrin was supported by the immunological studies of Monaco, Lythgoe, and Waddell (1961), and the physiological studies of Jackson and his colleagues (Jackson, Blair, Dawson, Reed, and Watts, 1963). Aminoacid analysis of an acid hydrolysate by Gregory, Grossman, Tracy, and Bentley (1967) showed that the substance elaborated by the tumour

${ }^{1}$ Member of the external scientific staff, Medical Research Council. had an amino-acid composition similar to the antral hormone gastrin.

The development of a bio-assay technique for the recognition of circulating gastrin, using the rat, by Lai (1964) was extended by us as a method of diagnosis in patients with clinical suspicion of the disease (Thomson and Sircus, 1967). Others have used the cat (Blair and Wood, 1968).

Recently an immunological assay has been developed by McGuigan and Trudeau (1968). This demonstrates the existence of an immunologically active protein in the circulation but does not establish that this material is physiologically active and therefore the method has limitations.

We report here our experiences to date with the modification of bio-assay by the method of Lai (1964) in the rat for use in clinical diagnosis.

\section{Patients}

Plasma from 42 patients was examined. In all but a few cases neither the history, nor the results of other investigations, nor the findings at operation or necropsy were known to the workers performing the assay. Ten of these 
patients served as controls. Of these, two were normal healthy adults, two had neoplastic disease of the alimentary tract but with no suspicion of the Zollinger-Ellison syndrome, one had Crohn's disease of the jejunum, and five had benign peptic ulcer disease without any unusual features. The remaining 32 subjects were patients with clinical features generating suspicion of the syndrome.

In arriving at definitive clinical diagnoses for the purpose of analysis of the results, we have used all data available to date from the physicians and surgeons in whose care the patients were. Thus far, twelve patients have been shown by operation, or by necropsy study, to have had either islet-cell tumour in the pancreas or at the ectopic sites of that organ, or to have had significant islet-cell hyperplasia. In some cases extracts of the tumours found have shown gastrin-like activity. Of the remaining 20 patients, 10 have been considered as a result of investigation, operation, and their subsequent clinical course, to be unlikely to be examples of the syndrome. Thus, there are ten patients in whom clinical suspicion remains until operation or necropsy supplies the evidence and in whom a definitive diagnosis cannot yet be made. The basis for clinical suspicion has been the subject of previous reviews (Sircus, 1962 and 1968).

\section{Methods}

Venous blood was withdrawn after an overnight fast, and collected in lithium-heparin tubes. It was centrifuged as rapidly as possible after withdrawal for 15 minutes at $1,200 \mathrm{~g}$ at $5^{\circ} \mathrm{C}$ and the resulting plasma was equally rapidly separated and stored at $-20^{\circ} \mathrm{C}$ in $2.5 \mathrm{ml}$ aliquots. Approximately one hour before it was required for assay, an aliquot was thawed at not higher than $30^{\circ} \mathrm{C}$ and immediately recentrifuged at $5^{\circ} \mathrm{C}$. The resulting defibrinated plasma was then assayed with no further manipulation. No sample was frozen or thawed more than once.

The assays for gastrin-like activity in all preparations were carried out on the modified anaesthetized-rat preparation as previously described by Thomson and Sircus (1968). The reference standards used in this study were appropriate dilutions of Peptavlon (ICI 50123). Several techniques have been investigated in an attempt to improve the sensitivity of the preparation, since, using this assembly, the infusion of $1.2 \mu \mathrm{g}$ Peptavlon (ie, $6 \mu \mathrm{g} / \mathrm{kg} / 15 \mathrm{~min}$ ) is required to produce significant acid secretion in most animals. Various manipulations of the animal have been tried, including filling the ruminant space of the stomach with a Perspex plug to reduce the dead space, but have proved unrewarding. Clamping off the ruminant portion

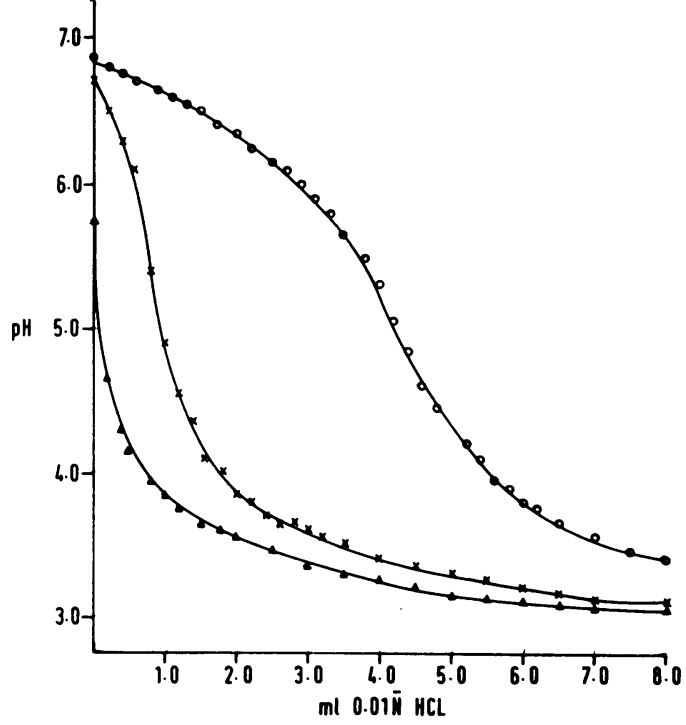

Fig. 1 Titration curves of buffers. $(\mathrm{O}-\mathrm{O}$ $1.54 \times 10^{-3} \mathrm{M}$ phosphate, $2.3 \times 10^{-4} \mathrm{M}$ citrate, and $1.54 \times 10^{-1} \mathrm{M}$ sodium chloride. $\times-\times$ $6.16 \times 10^{-4} \mathrm{M}$ phosphate, $9 \cdot 2 \times 10^{-5} \mathrm{M}$ citrate, and $1.54 \times 10^{-1} \mathrm{M}$ sodium chloride. $\triangle \longrightarrow \triangle$ $1.54 \times 10^{-1} \mathrm{M}$ sodium chloride.)

of the stomach minimizes stasis, with its attendant baseline fluctuation, and we believe also increases sensitivity somewhat. Precautions are taken to exclude the liver and the spleen from the clamp. This is attached at one end to the ligature on the ruminant portion and at the other to a pin fixed in the cork mat on which the rat 3 . is resting. Occasionally, unresponsive animals $\delta$ are encountered, in whom secretion can only be induced by the infusion of $20 \mu \mathrm{g}$ Peptavlon $ᄋ$ or more per $\mathrm{kg} / 15$ minutes. Such animals were not used for the studies described in this paper.

Sensitivity of the assay assembly can, however, be further improved by altering the concentration of of the perfusing buffer, and some of the analyses $N$ reported here were carried out using this modi- N fication. This buffer $\left(6.16 \times 10^{-4} \overline{\mathrm{M}} \mathrm{Na}_{2} \mathrm{HPO}_{4}\right.$ : $9.2 \times 10^{-5} \overline{\mathrm{M}}$ citric acid: $1.54 \times 10^{-1} \overline{\mathrm{M}} \mathrm{NaCl}, \stackrel{o}{\circ}$ $\mathrm{I}=* \cdot 156, p \mathrm{H} 6 \cdot 6$ ), as with the original, permits an approximately linear $p \mathrm{H}$ response to unit ? additions of acid, but yields a titration curve more responsive to small amounts of added acid and is therefore valuable in the assay assembly for assessing low concentrations of $\mathbb{\mathbb { D }}$ humoral activity (Figure 1). Using this buffer, significant acid secretion can usually be demonstrated with $0.48 \mu \mathrm{g}$ Peptavlon $(2.4 \mu \mathrm{g} / 15$ minutes). Since the rat's response to gastrin II is some four times higher than the response to Peptavlon on a weight for weight basis, secretion produced in response to the infusion of $0.10 \mu \mathrm{g}$ gastrin II should therefore be readily observed in the assay when using the dilute buffer. 
ASSAY PROTOCOL

In practice, assay of plasma preparations for gastrin-like activity was normally carried out using the following protocol. A primer dose of $0.6 \mu \mathrm{g}$ Peptavlon was infused over 15 minutes. If this produced a brisk secretion of gastric acid into the perfusing buffer, then the animal was regarded as sufficiently sensitive for serum assay. After the baseline secretion had been re-established for 15 to 30 minutes, $10 \mathrm{mg}$ hydrocortisone hemisuccinate in $0.5 \mathrm{ml} 0.9 \% \mathrm{NaCl}$ was injected subcutaneously, and immediately thereafter $2.0 \mathrm{ml}$ of suitably prepared test plasma was infused over 25 minutes. When possible, after the original baseline secretion was restored, a second sample from another patient was infused similarly and the analytical run terminated with a further infusion of $0.6 \mu \mathrm{g}$ Peptavlon for 15 minutes.

Duplicate analyses were carried out on all sera when sufficient was available and where a result was still in doubt further assays were performed. Dose order was reversed in the duplicate analysis, so that the plasma analysed first in the original assay was analysed second in the duplicate assay. It was hoped to avoid possible serum interaction in this way.

\section{CRITERIA FOR A POSITIVE BIO-ASSAY RESPONSE}

A sample was only regarded as giving a positive response when all three of the following criteria were fulfilled. (1) The $p H$ of the perfusing buffer started to drop during the course of, or within five minutes of the end of, the test infusion. (2) The drop in $p \mathrm{H}$ exceeded $0.2 \mathrm{pH}$ unit. (A rat was not used for assay work if the baseline $p \mathrm{H}$ fluctuation was greater than $\pm 0.1 \mathrm{pH}$ unit.) (3) The $p H$ of the perfusate returned to the original baseline $\pm \mathbf{0 \cdot 1} \mathrm{pH}$ unit.

A typical tracing of a complete analysis is shown (Fig. 2), with one plasma sample producing

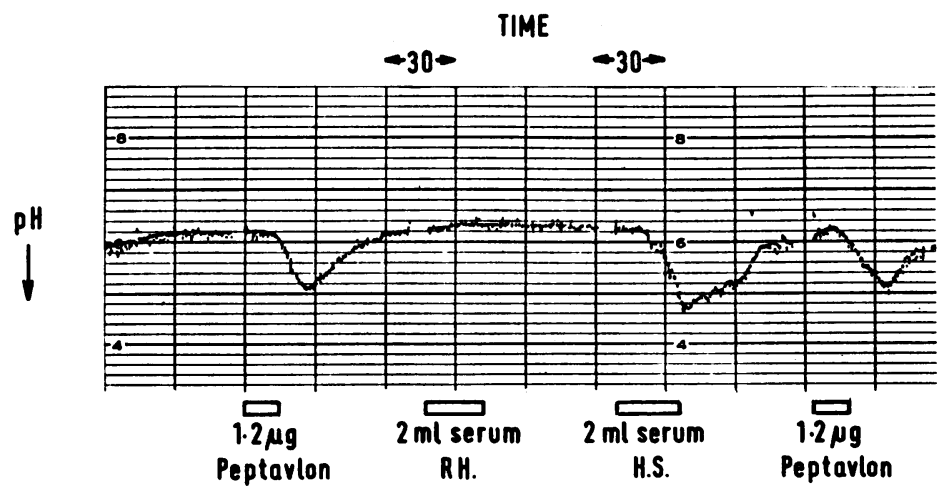

a positive response while the other shows no stimulation of secretion.

\section{VALIDATION OF METHOD}

It was deemed desirable to carry out the minimum manipulation of material from patients before analysis for gastrin-like activity, thus avoiding, it was hoped, the destruction of such activity or the introduction of artefacts into the assay. However, this necessitated establishing that there was no interference from other possible gastric secretagogues. The rat is notoriously insensitive to histamine (Kahlson, Rosengren, Svahn, and Thunberg, 1964); this was confirmed in this study. Infusion of $120 \mu \mathrm{g}$ histamine acid phosphate produced minimal secretion in a rat which had previously responded briskly to $0.48 \mu \mathrm{g}$ Peptavlon. Similarly, 20 milli-units bovine insulin (Wellcome) did not stimulate acid secretion in a rat which had secreted well in response to $1.2 \mu \mathrm{g}$ Peptavlon. Neither bradykinin (600 ng) nor 5-hydroxytryptamine $(2.4 \mu \mathrm{g})$ produced secretion in sensitive rats. The amounts of test materials used were chosen to be well in excess of the highest reported serum concentration of the agent in question. These findings were regarded as circumstantial evidence in support of our concept that any secretagogue detectable in plasma was gastrin or chemically closely allied to gastrin. Further direct support has come from the biological assay for histamine of some of the samples which gave a positive response in the gastrin bio-assay. The histamine assays all proved to be negative.

\section{Results}

Clinical information was correlated with bioassay findings only after completion of analyses of the plasma samples. Table I correlates the essential clinical information with the results of assays for individual patients, while Table II summarizes the overall results. In this table there is at first sight a discrepancy between the numbers in columns 2 and 3 and those in column 4. This is, however, not a true inconsistency but arises because, in a few patients, the examination of the total assay information left the diagnostic assessment as uncertain, despite the finding of positive or negative assays. In these cases, the occurrence of one or more technically unsatisfactory ('doubtful') assays detracted from the reliability of the assay information as a whole.

\section{Discussion}

In the ten control patients (group I) the results were clear cut, all 24 assays being negative. 


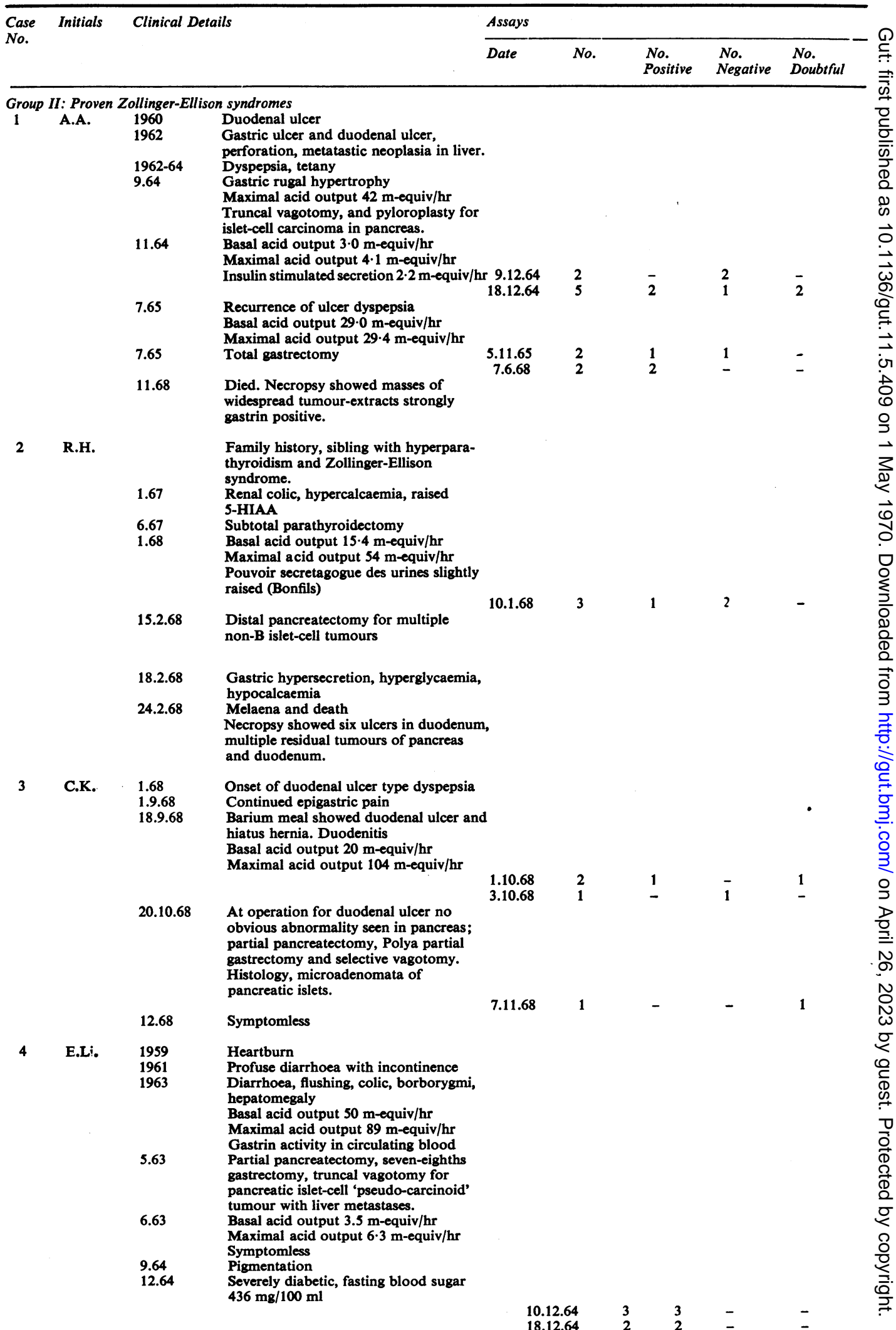




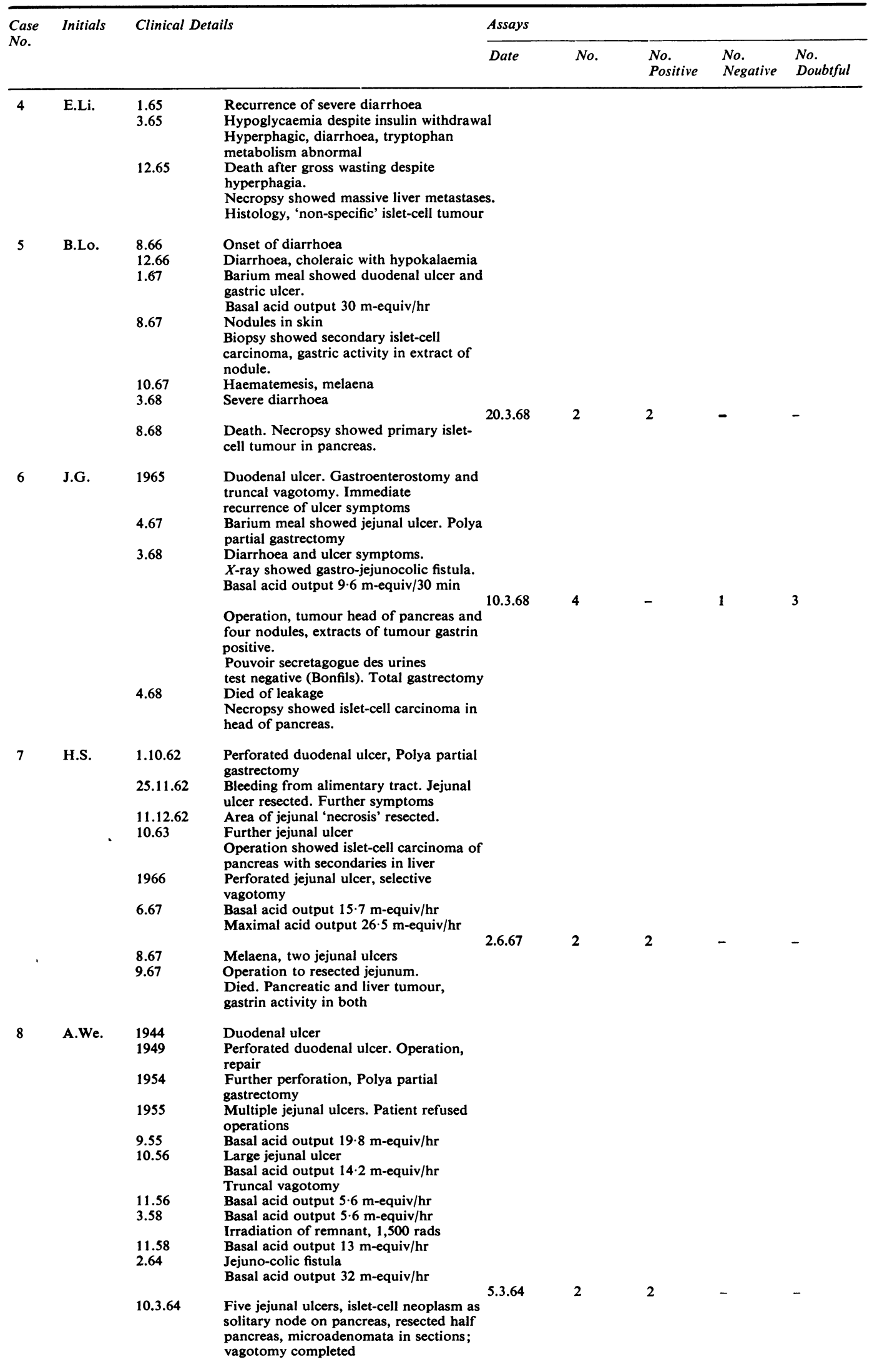




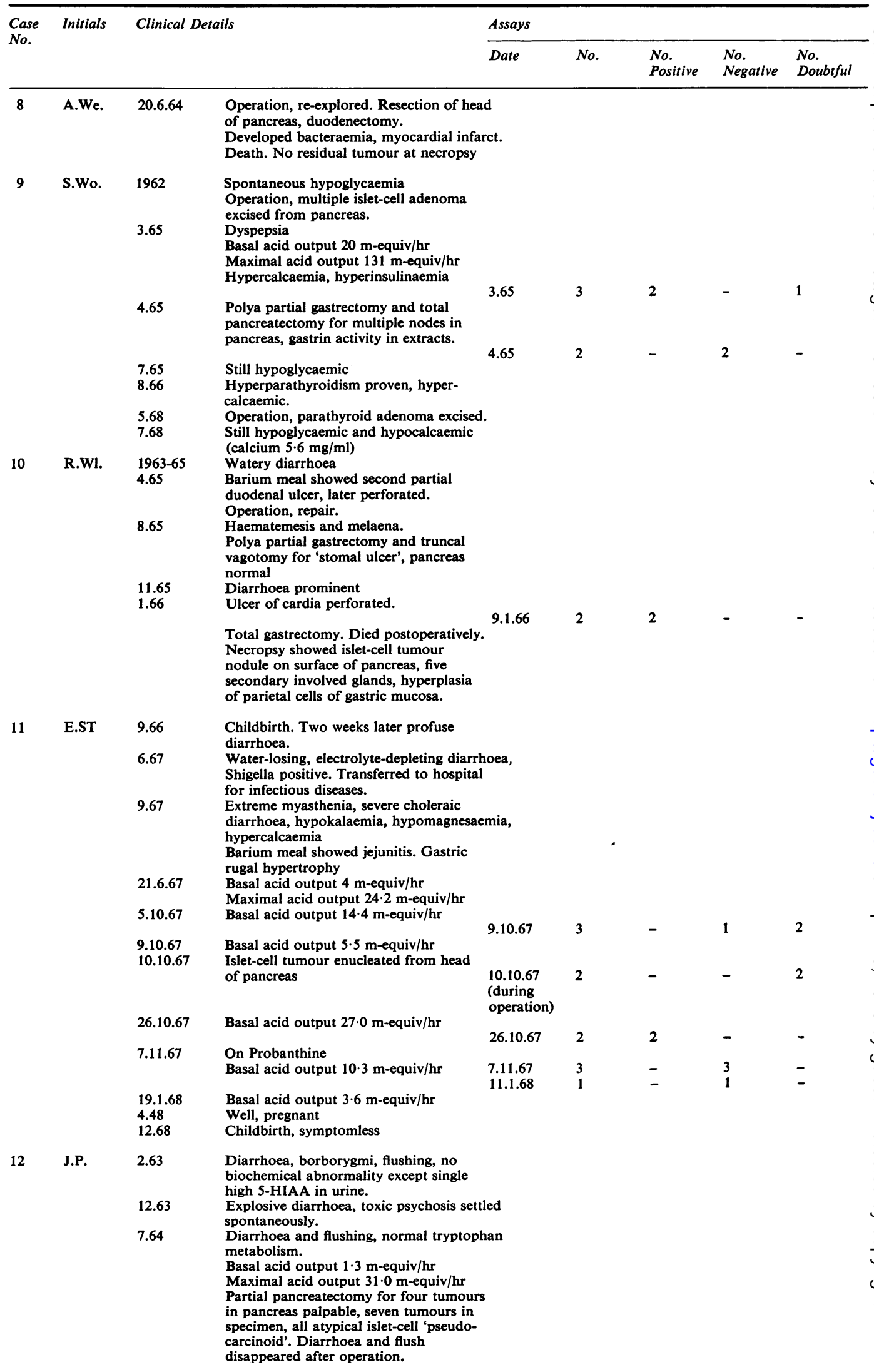




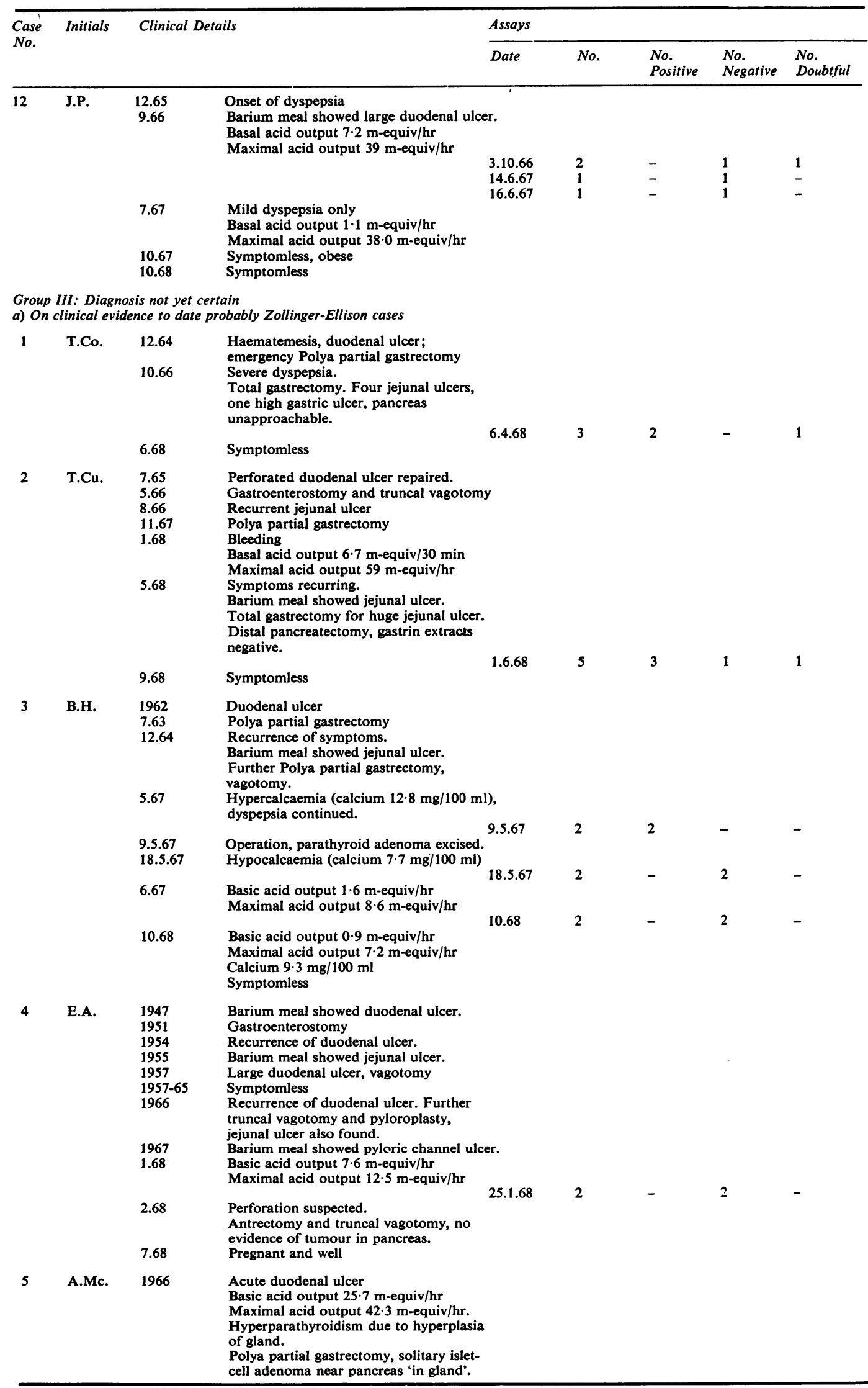




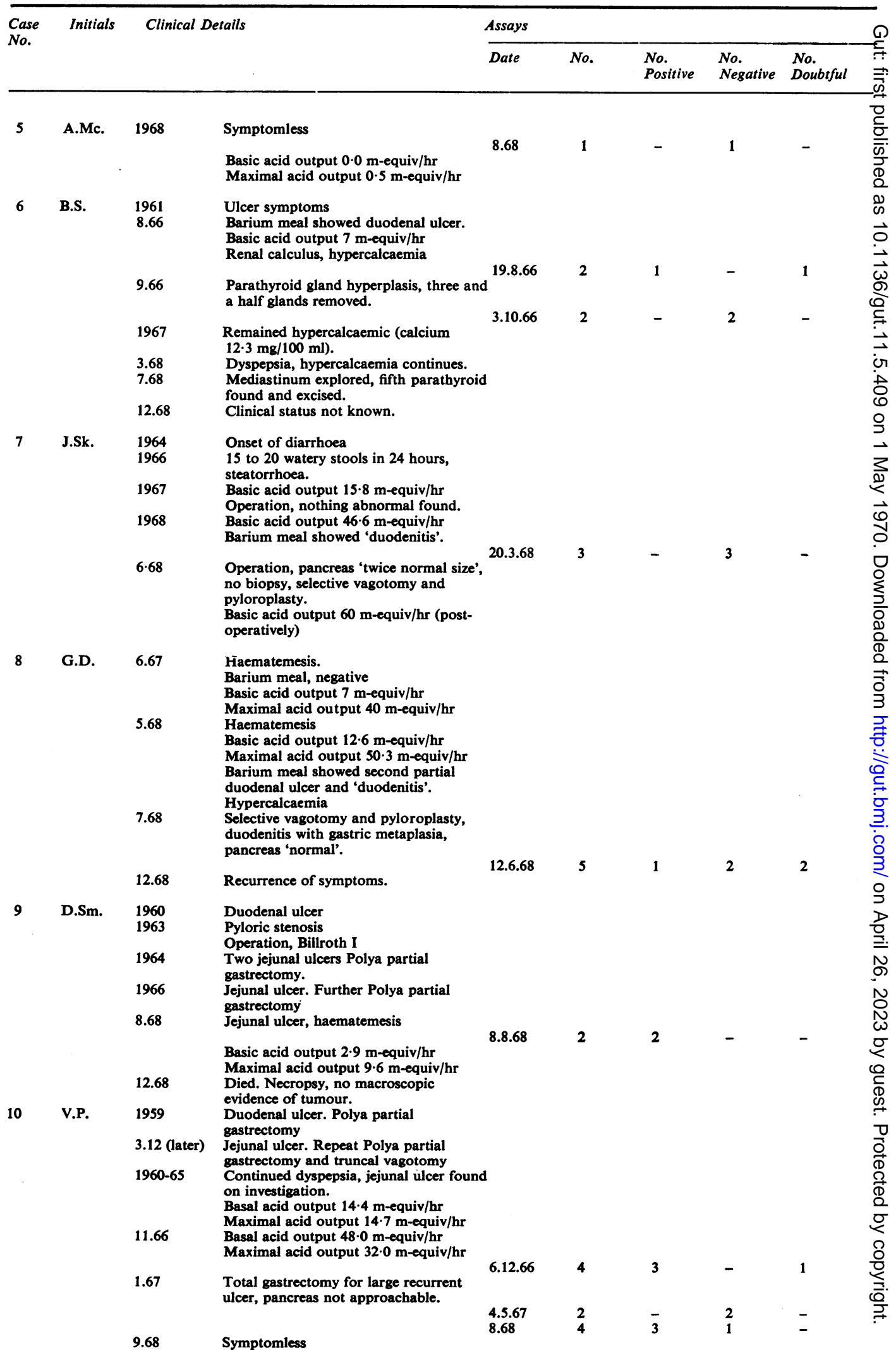




\begin{tabular}{lllllll}
\hline $\begin{array}{l}\text { Case } \\
\text { No. }\end{array}$ & Initials & Clinical Details & & & Assays \\
\cline { 3 - 6 } & & Date & No. & $\begin{array}{l}\text { No. } \\
\text { Positive }\end{array}$ & $\begin{array}{l}\text { No. Negative } \\
\text { Noubtful }\end{array}$ \\
\hline
\end{tabular}

b) On clinical evidence to date unlikely to be cases of Zollinger-Ellison syndrome

\begin{tabular}{|c|c|c|c|c|c|c|}
\hline 1 & D.Co. & $\begin{array}{l}\text { Recurrent jejunal ulcer following } \\
\text { gastroenterostomy for duodenal ulcer. }\end{array}$ & 3 & - & 3 & - \\
\hline 2 & J.Cr. & $\begin{array}{l}\text { Negative laparotomy for diarrhoea, } \\
\text { abdominal pain. } \\
\text { Basal acid output } 29 \text { m-equiv/hr }\end{array}$ & 2 & - & 2 & - \\
\hline 3 & м.H. & $\begin{array}{l}\text { Recurrent jejunal ulcer after Polya } \\
\text { partial gastrectomy for duodenal ulcer } \\
\text { (antral remnant). }\end{array}$ & 3 & - & 2 & 1 \\
\hline 4 & J.M. & $\begin{array}{l}\text { Recurrent jejunal ulcer after Polya } \\
\text { partial gastrectomy for duodenal ulcer/ } \\
\text { gastric ulcer. }\end{array}$ & 2 & - & - & 2 \\
\hline 5 & C.C. & $\begin{array}{l}\text { Recurrent jejunal ulcer after Polya } \\
\text { partial gastrectomy and truncal vagotomy } \\
\text { plus pyloroplasty. }\end{array}$ & 7 & 1 & 6 & 3 \\
\hline 6 & E.P. & $\begin{array}{l}\text { Recurrent jejunal ulcer after Polya } \\
\text { partial gastrectomy and truncal } \\
\text { vagotomy. }\end{array}$ & 2 & - & 2 & - \\
\hline 7 & D.H. & $\begin{array}{l}\text { Multiple duodenal ulcers } \\
\text { Basal acid output } 24 \text { m-equiv/hr }\end{array}$ & 3 & - & 2 & 1 \\
\hline 8 & J.S. & $\begin{array}{l}\text { Multiple duodenal ulcers } \\
\text { Basal acid output } 21 \text { m-equiv/hr }\end{array}$ & 3 & - & 3 & - \\
\hline 9 & D.S. & $\begin{array}{l}\text { Perforated duodenal ulcer } \\
\text { Basal acid output } 10.2 \mathrm{~m} \text {-equiv } / \mathrm{hr} \\
\text { Nodular pancreas } \\
\text { Maximal acid output } 78.6 \mathrm{~m} \text {-equiv } / \mathrm{hr}\end{array}$ & 4 & - & 3 & 1 \\
\hline 10 & A.D. & Duodenal ulcer, nodular pancreas & 2 & - & 2 & - \\
\hline
\end{tabular}

Table I Summaries of the clinical histories and the bio-assay results of all patients studied-concluded

\begin{tabular}{|c|c|c|c|c|c|c|}
\hline \multirow[t]{2}{*}{ Group } & \multirow{2}{*}{$\begin{array}{l}\text { Clinical } \\
\text { Classification }\end{array}$} & \multirow[t]{2}{*}{ Total } & \multicolumn{4}{|c|}{ Number of Subjects } \\
\hline & & & $\begin{array}{l}\text { With One } \\
\text { or More } \\
\text { Positive } \\
\text { Assay }\end{array}$ & $\begin{array}{l}\text { With all } \\
\text { Assays } \\
\text { Negative }\end{array}$ & $\begin{array}{l}\text { Diagnosis } \\
\text { Uncertain } \\
\text { from Assays }\end{array}$ & $\begin{array}{l}\text { Total } \\
\text { Number of } \\
\text { Assays }\end{array}$ \\
\hline $\begin{array}{l}\text { I } \\
\text { II }\end{array}$ & $\begin{array}{l}\text { Controls } \\
\text { Confirmed by histo- } \\
\text { pathology as peptide- } \\
\text { secreting adenoma } \\
\text { of pancreas }\end{array}$ & $\begin{array}{l}10 \\
12\end{array}$ & $\begin{array}{l}0 \\
10\end{array}$ & $\begin{array}{r}10 \\
0\end{array}$ & $\begin{array}{l}\mathbf{0} \\
\mathbf{3}\end{array}$ & $\begin{array}{l}24 \\
62\end{array}$ \\
\hline III & $\begin{array}{l}\text { Diagnosis not defined, } \\
\text { on clinical data } \\
\text { probably peptide- } \\
\text { secreting adenoma }\end{array}$ & & 7 & 3 & 4 & 41 \\
\hline III & $\begin{array}{l}\text { Diagnosis not defined, } \\
\text { on clinical data } \\
\text { improbably peptide- } \\
\text { secreting adenoma }\end{array}$ & & 1 & 5 & 2 & 34 \\
\hline
\end{tabular}

Table II Comparison of clinical diagnosis with results of plasma bio-assay

${ }^{1}$ Details of the number of patients in whom the diagnosis remained uncertain after survey of the assay results for each individual.

Sixty-two assays were carried out on the twelve patients ultimately shown to have proven peptide-secreting adenomata (group II, Table I). Of these assays, 25 were positive, 25 negative, and the remaining 14 were technically unsatisfactory in some way.

In their observations on bio-assays carried out on the sera of 25 patients with the ZollingerEllison syndrome, in 15 patients Wilson, Mathison,
Schulte, and Ellison (1968) found that the results were consistently negative and postulated reasons for this. Our experience, and especially the clinical suggestion of a relationship between the stage of activity and extant mode of presentation of the disease and the result of a particular assay, supports the probability that the explanation lies more likely in fluctuation of circulating gastrin levels rather than in technical inadequacies of the bio-assay. It appeared that unequivocal positive assays were obtained when the patients showed active disease clinically, while assays were negative or equivocal when the patient appeared to be in clinical remission, or, alternatively, after satisfactory removal of primary tumour, either from the pancreas or the parathyroid (see patients A.A., A.W., S.W. and E.S. in group II, Table I). In one of this group, (J.P.) analyses were only performed after a partial pancreatectomy had resulted in the removal of multiple tumours, since when the patient's clinical condition has been satisfactory. Thus this patient is classified in Table II as having an uncertain diagnosis on the basis of the assay findings. The other two patients so classified in this group are R.H. and J.G.

Of the remaining 20 patients who cannot yet be diagnosed with certainty, the clinical developments suggest that the syndrome is present in ten patients (group IIIa, Table I) 
and a positive assay has been obtained on one or more occasions in seven of these cases. Patient G.D., however, must fall into the classification 'diagnosis uncertain on the basis of assay', due to the variation in assay results. The other patients, B.S. and B.H., who might be expected also to be thus classified are, however, regarded as 'assay-positive' since, before their operations, their plasmas did not give negative assays. There are in this group three patients with clinical features consistent with a probable diagnosis of peptide-secreting adenoma, as yet unproven, in whom assays have so far been negative. In one case (A.Mc.) only one assay has been performed, while in the other two (E.A. and J.Sk.) only single plasma specimens have been available for assay.

In group IIIb, there are nine patients who are unlikely on clinical grounds to have other than benign peptic-ulcer disease and none of the 24 assays was positive. One patient in this group (C.C.) has so presented clinically that her diagnosis remains uncertain; her early history is not that usually seen in ordinary peptic-ulcer disease, but her recent clinical behaviour since her second operation does not give sufficient grounds to exclude her from this group of patients. Of the 10 assays carried out on her over two years, one has been positive, six negative, and three doubtful, so that on the criterion of assay she must also be classified as uncertain. One other patient (J.M.) must also be placed in this category, because both attempts at assay of his plasma resulted in death of the assay animals.

We believe that this bio-assay method has a role to play in the diagnosis of peptide secreting adenomata, in that our results suggest that a positive result on bio-assay is very strongly indicative of presence of tumour. Out of 161 assays on 42 patients only one assay has been recorded as positive where there is not strong circumstantial or conclusive evidence on clinical grounds of secreting tumour. However, in 22 patients with probable or certain evidence of tumour, there were 22 negative assays recorded on serum samples taken when functioning tumour was probably present and 20 assays which had to be classified as technically doubtful.

Several explanations may be advanced for the finding of a negative assay with plasma from a patient with a secreting tumour. Referenze has already been made to the possibility of variation of concentration of circulating secretagogue reflecting the clinical state. In support of this is the finding of the greatest concentration of hormonal activity in our entire series in the final plasma sample from patient A.A. (group II, Table I) taken when metastases were widespread. Allied to this concept is the suggestion that there is a phasic pattern in the behaviour of such tumours (Sircus, 1968) and, for example, that tumour may secrete predominantly a gastrin- like humoral agent at one stage in the clinical condition, and other agents at other times. ه

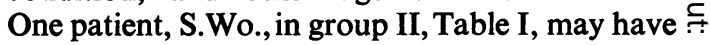
had such a multipotential tumour.

There are, however, additional factors implicit in the assay method that may explain the negative $\frac{\mathrm{C}}{\mathrm{O}}$ assays. Variation in rat sensitivity can be con- $\frac{\bar{O}}{\bar{c}}$ siderable and associated with this is the variation $\frac{\sigma}{\sigma}$ in the slope of the dose-response curve from one $ᄋ$ animal to another (Lai, 1964). As each assay is \& carried out on a different animal, the same $\overrightarrow{0}$ specimen of plasma may produce a positive $\vec{\overrightarrow{ }}$ response in one animal but a negative in another $\vec{\omega}^{\circ}$ (for example, patient T.Cu. in group IIIa).

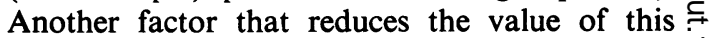
technique is represented by the 'doubtful' assays. $\overrightarrow{.}$ Among this group of assays are those carried ir out on animals who died during infusion of the $\vec{\theta}$ test plasma. While hydrocortisone injection reduced the incidence of 'plasma deaths', it did not remove it completely and some specimens $\vec{z}$ of plasma were particularly notable for causing death during or just subsequent to infusion (eg, patient J.G., group II, and patient J.M., $\stackrel{Ð}{0}$ group IIIb).

The question is thus posed of another animal preparation that would be free of these limitations. Assay using the anaesthetized cat appears to offer an increased sensitivity (Blair, Keenlyside, $\stackrel{\nu}{\circ}$

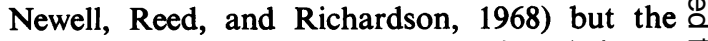
high cost of such preparations restricts their use $\overrightarrow{\overrightarrow{0}}$ in clinical assessment. It may be that cats pro- $\exists$ vided with permanent cannulated gastric fistulae $\rightleftharpoons$ (Uvnäs and Emas, 1961) may offer a useful alternative to both the rat and the anaesthetized $\frac{\alpha}{\sigma}$ cat.

Since the preparation of this report increasing experience of the method with further cases is yielding still more consistent and reproduciable $\stackrel{\circ}{\ni}$ results. The method is now being applied on a service basis to hospitals.

We should like to thank Dr H. Adam of the Depart- N ment of Pharmacology for performing the histamine assays, and Professor R. A. Gregory who provided extracts from necropsy material.

\section{References}

Bank, S., and Marks, I. N. (1964). Circulating gastric secretagogue in Zollinger-Ellison syndrome. Lancet, 2, 1012-1013.

Blair, E. L., Keenlyside, R. M., Newell, D. J., Reed, J. D., and $\bar{D}$ Richardson, D. R. (1968). Assay of gastrin by means of $\overparen{T}$ its gastric acid stimulating activity. J. Physiol. (Lond.), 198, 613-626.

Blair, E. L., and Wood, D. D. (1968). The estimation of gastrin activity in blood. J. Physiol. (Lond.), 194, 44-45P.

Gregory, R. A., Grossman, M. I., Tracy, H. J., and Bentley, P. H. (1967). Nature of the gastric secretagogue in ZollingerEllison tumours. Lancet, 2, 543-544.

Gregory, R. A., Tracy, H. J., French, J. M., and Sircus, w. (1960). Extraction of a gastrin-like substance from a pancreatic tumour in a case of Zollinger-Ellison syndrome. Lancet, 1, 1045-1048.

Jackson, R. H., Blair, E. L., Dawson, P. J., Reed, J. D., and Watts, W. P. T. (1963). Gastrin activity of tumour tissue in a child with the Zolling $3 r-E l l i s o n$ syndrome. Lancet, 2 , 908-912. 
Kahlson, G., Rosengren, E., Svahn, D., and Thunberg, R. (1964). Mobilisation and formation of histamine in the gastric mucosa as related to acid secretion. J. Physiol. (Lond.), $174,400-416$.

Lai, K. S. (1964). Studies on gastrin. Gut, 5, 327-341.

McGuigan, J. E., and Trudeau, W. L. (1968). Immunochemical measurement of elevated levels of gastrin in the serum of patients with pancreatic tumours of the Zollinger-Ellison variety. New Engl. J. Med., 278, 1308-1313.

Monaco, A. P., Lythgoe, J. P., and Waddell, W. R. (1961) Immunological study in the Zollinger-Ellison syndrome. Lancet , 2, 1016-1017.

Sircus, W. (1962). Lessons from the Zollinger-Ellison syndrome. In Surgical Physiology of the Gastro-intestinal Tract: Proceedings of a Symposium, edited by A. N. Smith, pp. 92-98. Royal College of Surgeons, Edinburgh.

Sircus, W. (1964). Evidence for a gastric secretagogue in the circulation and gastric juice of patients with the ZollingerEllison syndrome. Lancet, 2,671-672.

Sircus, W. (1968). Peptide secreting adenomata with special reference to the Zollinger-Ellison syndrome. Postgrad. med.J., 44, 742-748.

Thomson, C. G., and Sircus, W. (1967). Experiences with a bioassay method for the diagnosis of the Zollinger-Ellison syndrome. Gut, 8, 632 .

Thomson, C. G., and Sircus, W. (1968). III. The action of the rat. Effects of SC 15396 on gastric secretion, Gut, 9, 649-651.

Uvnäs, B., and Emas, S. (1961). A method for biologic assay of gastrin. Gastroenterology, 40,644-648.

Wilson, S. D., Mathison, J. A., Schulte, W. J., and Ellison, W. H. (1968). The role of bioassay in the diagnosis of ulcerogenic tumors. Arch. Surg., 97, 437-443.

Zollinger, R. M., and Ellison, E. H. (1955). Primary peptic ulcerations of the jejunum associated with islet-cell tumours of the pancreas. Arch. Surg., 142, 709-728.

\section{The April 1970 Issue}

\section{THE APRIL 1970 ISSUE CONTAINS THE FOLLOWING PAPERS}

Small-intestinal mucosal abnormalities in various skin diseases-fact or fancy? JANET MARKS AND SAM SHUSTER

Dermatogenic enteropathy JANET MARKS AND SAM SHUSTER

Effect of graded doses of pentagastrin in patients with and without gastritis A. BERSTAD AND J. MYREN

The cricopharyngeal sphincter in gastric reflux P. S. HUNT, A. M. CONNELL, AND T. B. SMILEY

Diagnostic procedure in bleeding of obscure origin from the alimentary canal FRANZ BÁRÁNY AND LARS H:SON NILSSON

Urinary crystalloid excretion in patients with inflammatory bowel disease RICHARD I. BREUER, EUGENE A. GELZAYD, AND JOSEPH K. KIRSNER

Observations on an unusual enzyme distribution pattern in the colon of a case of familial polyposis with malignant changes V. MAGGI AND A. P. WYATT

Familial polyposis coli associated with extracolonic abnormalities T. G. PARKS, H. J. R. BUSSEY, AND H. E. LOCKHART-MUMMERY
Measurement of electrical potentials of the human rectum and pelvic colon in normal and aldosterone-treated patients C. J. EDMONDS AND R. C. GODFREY

Incidence and clinical significance of lactose malabsorption in ulcerative colitis and Crohn's disease E. GUDMAND-HøYER AND STIG JARNUM

Inhibition of peptic activity by carbenoxolone and glycyrrhetinic acid F. D. HENMAN

Gastric anthrax with massive ascites w. DUTZ, F. SAIDI, AND E. KOHOUT

Variation in the $p \mathrm{H}$ of faeces in disease $\mathrm{N}$. MADANAGOPALAN, S. ARUMUGAN NADAR, AND R. SUBRAMANIAM

Radiological anatomy after pyloroplasty D. K. M. TOYE, J. F. K. HUTTON, AND J. ALEXANDER WILLIAMS

Progress report On antibodies to gastrin: concerning their production, behavioural characteristics, and uses JAMES E. MCGUIGAN

The British Society of Gastroenterology

Notes and Activities

Copies are still available and may be obtained from the PUBLISHING MANAGER, BRITISH MEDICAL ASSOCIATION, TAVISTOCK SQUARE, W.C.1. price 17s. 6D. 